\title{
Investigating the Effectiveness of Audio Input Enhancement on EFL Learners' Retention of Intensifiers
}

\author{
Giti Mousapour Negari \\ University of Sistan and Baluchestan, Iran,mousapour@hamoon.usb.ac.ir
}

\author{
Aliye Azizi \\ University of Sistan and Baluchestan, Iran, aliyeazizi19@gmail.com

\section{Davood Khedmatkar Arani} \\ University of Sistan and Baluchestan, Iran, davood khedmatkararani@yahoo.com
}

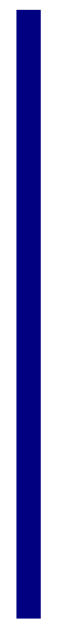

\begin{abstract}
The present study attempted to investigate the effects of audio input enhancement on EFL learners' retention of intensifiers. To this end, two research questions were formulated. In order to address these research questions, this study attempted to reject two null hypotheses. Pretest-posttest control group quasi-experimental design was employed to determine the extent to which audio input enhancement could have an effect on the retention of intensifiers by EFL learners. Cluster sampling was used and 43 students participated in the study. They were assigned into two groups: an audio input enhancement group and a control group. A multiple choice test of English intensifiers was used during three phases of the study to collect the required data. The reliability of the test was estimated to be 0.74. At the initial stage, English - Beginner Test was administered to assure the students' homogeneity. Before implementing the treatment, a pre-test consisting of 20 multiple-choice items on intensifiers was administered to ensure that the participants' knowledge of the target forms was more or less the same. English intensifiers were taught through audio input enhancement in the experimental group; however, no input enhancement was applied in the control group.
\end{abstract}

Keywords: audio input enhancement, English intensifiers, retention, EFL learners, learning, teaching

\section{INTRODUCTION}

Early approaches to second language learning placed emphasis on various notions such as rote learning, memorization, and repetitive drills. Grammar-translation method is a direct and obvious corollary of these approaches. Since the emergence of Krashen's (1981) input hypothesis, a substantial shift has occurred in second language acquisition (SLA) emphasis. It was argued that effective language learning best occurs through

Citation: Negari, G. M., Azizi, A., \& Arani, D. K. (2018). Investigating the Effectiveness of Audio Input Enhancement on EFL Learners' Retention of Intensifiers. International Journal of Instruction, 11(1), 123-138. https://doi.org/10.12973/iji.2018.1119a 
meaningful use of language and comprehensible input (Krashan, 1981). So, the practical ramifications of these two approaches are Communicative Language Teaching (CLT) and Natural approach.

The focus has gradually shifted from form-based approaches to meaning-based ones, which may dispossess students of the morpho-syntactic features acquisition. As these two approaches to language learning are two extremes of one continuum, researchers were convinced to come up with a Focus on Form (FOF) approach, which enables the reconstruction of interlanguage through form-function mapping (Doughty, 2001). FOF acts as a fuzzy control system which supervises learners' incoming system based on fuzzy logic, where values do not necessarily have to be either 0 or 1 ; rather they can vary somewhere between these two extremes. This system analyses input values in terms of linguistic accuracy using focused task where both meaning and linguistic forms are attended. This is in sharp contrast to previous approaches, which functioned on discrete values of either focus on form or focus on meaning. Because of the significant role of FOF in second language development, some researchers asserted that FOF should be emphasized greatly in the case of adult learners (Nassaji, 2009; Rahimpour et al., 2012). The process can be carried out through enhancement of the input with which learners are presented.

It should be noted that the main goal of any teaching is to help learners better understand, remember, and use their learned knowledge, so it is very important to apply approaches that help learners achieve these goals. While past instructional treatments have been important in the study of second language acquisition, this study attempted to use audio materials as a means to provide learners with more salient target forms to draw their attention to them. Hence, the current research set out to examine the degree to which audio input enhancement could affect the retention of intensifiers by Iranian EFL learners. Moreover, the study attempted to determine whether the effect of the treatment on the dependent variable is stable or not.

The present study attempts to provide plausible answers to the following research questions:

1. Does audio input enhancement have any significant effect on the learning of intensifiers by Iranian EFL learners?

2. Does audio input enhancement have any significant effect on the long-term retention of intensifiers by Iranian EFL learners?

Based on the above research questions, the following null hypotheses are formulated:

H0 (Question 1): Audio input enhancement has no significant effect on Iranian EFL learners' learning of intensifiers.

H0 (Question 2): Audio input enhancement has no significant effect on Iranian EFL learners' long-term retention of intensifiers 


\section{REVIEW OF LITERATURE}

\section{Input}

The significance of input is well documented in the field of second or foreign language acquisition. Learning second/foreign language is not possible without exposure to some sort of input (Benati, 2001; Gass, 1997). VanPatte (1996) regarded input as a necessary element of second language acquisition because learners utilize it to internalize what they acquire. Input was regarded as an essential but insufficient condition for SLA (Larsen-Freeman \& Long, 1991). The input with which learners are provided should be converted into intake in order for language learning to take place. (Gass, 1997; VanPatten, 1996). Intake is defined as "a subset of the detected input (comprehended or not), held in short-term memory, from which connections with long-term memory are potentially created or strengthened" (Reinder, 2005, p. 73). Schmidt (1990) introduced the "Noticing Hypothesis" which stated that "noticing is the necessary and sufficient condition for the conversion of input to intake for learning" (Schmidt, 1994, p. 17). FOF is regarded as the only method that enhances noticing. In view of the significant role of grammar in the field of second or foreign language teaching, it has been crucial for teachers to apply an appropriate method to teach grammar specifically in English as foreign language contexts. Furthermore, Long (1991) proposed FOF approach as a useful solution for the problems of traditional approaches to grammar instruction as well as communication approaches which mainly emphasized meaning-focused communication. Spada (1997) defined FOF as a pedagogical approach which utilizes either an implicit or explicit method to direct attention of language learners to the target forms. Moreover, Doughty (2001) stated that focus on form is distinct from other approaches in which second language learners simultaneously focus on form, meaning, and use of target forms during a cognitive activity ( Gass, 1997).

\section{Input Enhancement}

Prior to presenting input enhancement, Sharwood Smith (1981) introduced consciousness-raising, by which he assumed that most of second/foreign language teaching/learning problems that occurred in focus on forms approaches could be efficiently addressed. Consciousness-raising means that the language instructor attempts to make language learners more conscious of the new target form(s). Additionally, Sharwood Smith (1991) argued consciousness-raising does not guarantee learners' ability to internalize the new target forms. Accordingly, he $(1991,1993)$ replaced the consciousness-raising term with input enhancement that can be controlled by the instructor. Input enhancement refers to techniques and methods which the instructor uses to make selected features of a second language more salient for learners to facilitate language acquisition (Sharwood Smith 1991, 1993). Kim (2006) defined input enhancement as "pedagogical techniques designed to draw learners' attention to formal features in the L2 input" (p. 345). Combs (2009) stated that the more salient a new form is, the more likely it is that the L2 learner will select it. Ellis $(1993,1995)$ also mentioned that input enhancement is an efficient alternative in language teaching. Its role is to raise learners' awareness of some specific target forms in learning context and direct their attention to them. Although researchers are yet to find a positive correlation 
between language learning and input, there has been noticeable work on manipulating input to facilitate its comprehension for learners (Ellis, 1997).

\section{Audio Input Enhancement}

In foreign language situations, it is more convenient to use input enhancement in written form (textual) than in oral form, whereby teachers apply audio materials or use special forms with more frequency in their classrooms. Limitations in traditional classrooms might be the reason for this convenience. Audio input enhancement is based on the manipulation of audio materials to make the target forms more salient and draw learners' attention to them (Seyedtajaddini, 2014).

In the literature of second/foreign language acquisition, most of the studies have investigated the effect of input enhancement regarded as an implicit procedure of a form-focused instruction on the acquisition of grammatical forms (e.g. Leow, 2000, 2001; Overstreet, 1998, 2002; Wong, 2003). In line with previous studies, the current study placed the emphasis on the effect of input enhancement on learning grammatical items, namely intensifiers.

\section{Intensifiers}

Intensifiers provide greater depth of meaning for the words they describe. Based on Quirk et al. (1985), the term is used as a modifier for both adjectives and verbs, but Allerton (1987) confined it to degree words occurring together with adjectives only. Quirk et al. (1985, p. 589) claimed, "[i]ntensifiers do not refer only to means whereby an increase in intensification is expressed", rather they "indicate a point on an abstractly conceived intensity scale; and the point indicated may be relatively low or relatively high". Their classification of intensifiers, which is the focus of this study, is as follows:

\section{Amplifiers}

a) Maximizers such as completely, absolutely

b) Boosters such as very, highly

\section{Downtoners}

a) Approximators such as nearly, virtually

b) Compromisers such as fairly, quite

c) Diminishers such as slightly

d) Minimizers such as hardly, scarcely

Recently, various investigations have focused on intensifiers because of their potential to affect communication and their linguistic developments (Barnfield \& Buchstaller, 2010; Mendez-Naya, 2008). It should be noted that most of the studies have evaluated how frequently they appear in particular languages; however, few of them have examined the teaching of intensifiers. To exemplify, Eslami-Rasekh and Mardani (2010) investigated the use of intensifying devices in apology speech act of Persian EFL 
learners. The results of their study showed that the group which had received explicit instructions applied intensifiers more appropriately and effectively.

\section{Empirical Studies}

A number of studies have examined how manipulating external saliency of input vis-àvis instruction may influence language learning.

Jabbarpoor and Abdollahzadeh (2013) evaluated the effect of textual input enhancement on adult foreign language intake of two English linguistic forms, i.e. subjunctive mood and inversion structures, to determine the role of the type of linguistic items in input enhancement studies. The participants of the study were thirty university students who were presented with twelve enhanced texts for subjunctive mood and twelve other texts for inversion structures. The results of the study supported the effectiveness of textual enhancement on the acquisition of two target forms by EFL learners. In particular, it showed that the form with more saliency (subjunctive mood) is significantly more beneficial compared to the form with less saliency (inversion structure).

Ayiewbey (2013) conducted a study to evaluate the effect of textual input enhancement on learning of English past tense in the case of Iranian Learners. The participants of the study were divided into two experimental groups and one control group. Three versions of the same reading were given to the participants, and they were asked to pay attention to the past tense forms of verbs which were embedded in the text. In the two experimental groups, the participants received the versions of the target structures which were enhanced by boldfacing and italicization. In the control group, the students were exposed to unenhanced target forms. The results indicated that textual enhancement was effective in learners' performance recognizing correct grammar points from incorrect ones. The two experimental groups (bold-faced and italicized groups) outperformed the control group in terms of distinguishing correct past tense structures.

Obviously, previous studies have focused greatly on written input enhancement; the reason may refer to the ease of implementations in traditional classes. However, few studies have investigated the effect of language input enriched through the manipulation of audio materials on the acquisition of target forms. For example, Cho and Reinders (2013) examined the effect of aural input enhancement in extensive listening on L2 acquisition. Participants in the experimental group received an audio book in which passive structures had been manipulated by artificially raising the volume of the target items and/or by reducing the speed with which the target items were read out. The control group listened to the unaltered audio files. The findings showed no significant aural input enhancement effect on acquiring the target form.

Seyedtajaddini's (2014) study examined the effect of audio input enhancement on EFL learners' grammar learning with different levels of proficiency. The results indicated that audio input enhancements have a more significant effect on high-proficiency students. The study also revealed that more proficient students show greater awareness and higher interest than less proficient students regarding the amount of audio input they received. Hence, audio input enhancement can be viewed as essential to effective learning. 
To sum up, the review of literature provided the theoretical arguments and empirical studies concerning input, noticing, FOF approach, input enhancement and audio input enhancement. However, the effects of audio input enhancement on intensifiers have not been sufficiently addressed in foreign language literature. The present study tries to shed some light on this issue.

\section{METHOD}

The current study explored the effect of audio input enhancement (independent variable) on the retention of intensifiers (dependent variable). Hence, quasi-experimental design, which is one of the quantitative research methods, was applied in order to assess the effectiveness of the independent variable (Leedy \& Ormrod, 2010). The study design involves two classes of the students assigned to experimental and control groups. In the experimental group, English intensifiers were taught through audio input enhancement. The participants in the control group, on the other hand, received the target forms through traditional methods. Moreover, in the present study, the data were analysed by using the Statistical Package for Social Science (SPSS) version 16. Furthermore, for all of the statistical analyses, the alpha level was set at 0.05

\section{Participants}

The participants of this study were 43 male sophomore students from two high schools in Aran and Bidgol, Isfahan. The study was carried out using cluster sampling technique. Due to some reasons such as time, money, and effort involved, the researchers tried to choose the sample from among a large number of high schools. Hence, according to Ary et al. (2014), in this case, it would be more convenient to choose a number of schools randomly to include all the students in those schools in the sample. The experimental group consisted of 23 students and the control group consisted of 20 students. In order to ensure that the drawn sample is representative of the target sample, the researchers identified the students' characteristics, which were similar to the target population such as their social backgrounds, their family situations, and their prior experiences regarding studying English language. The average age of the students was 17. To ascertain the learners' homogeneity, an English-Beginner Test was administered.

\section{Data Collection Tools}

The following research instruments were used in the present study:

\section{English Test- Beginner (proficiency test)}

To assure that all the participants were at the same level of language proficiency, English- Beginner Proficiency Test developed by Bertrand (n.d.) was administered at the commencement of the study. The test was piloted with another group of students who were at the same level as the participants of the present study before administration and its reliability was computed through KR-21 formula $(r=0.76)$. To ensure the content validity of the test, the comments of some experts were sought. Each strongly confirmed the appropriateness of the test concerning the general objective of measuring beginners' English proficiency. 


\section{Multiple Choice Test of English Intensifiers}

The first step in making the multiple-choice test used in this study was to provide a list of intensifiers that were frequent, but at a level fitting students' language proficiency. Some intensifiers were selected from two books: Basic and Expanding Tactics for listening (Richards \&Trew ,1943) and Top Notch (Saslow \& Asher, 1958) and some others were retrieved from the Internet (e.g.www.manythings.oral). The list was distributed among thirty students in the pilot group, who were at the same level of language proficiency as those who participated in the study. The list served to verify the participants' lack of familiarity with the chosen intensifiers. They were instructed to put a check mark on a word they knew and to provide a brief written explanation in either L2 or L1. The aim was to identify and, consequently, remove the intensifiers the participants were already familiar with. After removing the known intensifiers, the researcher designed a test in a multiple-choice format consisting of twenty questions. This test was administrated to the participants as the pre-test, post-test and delayed-test. The reliability of the test was calculated through Cronbach's alpha, which was 0.74 . Moreover, two experts confirmed the face validity of the test.

\section{Instructional Materials}

The researcher used the listening parts, some of which had been selected from Basic and Tactics for listening (Richards \&Trew ,1943) and Top Notch (Saslow \& Asher, 1958). The remainder had been retrieved from the Internet (e.g.www.manythings.oral). They were all used to present the experimental groups with audio input. The chosen listening extracts involved different types of English intensifiers, which were frequent in conversational contexts. The following short conversation is an example:

\section{A: Are the sneakers comfortable? \\ B: Well, I think they're a little small for me. \\ A: Too small? Let's find a bigger one.}

The selected materials differed from the students' course books. Furthermore, to make the materials more intelligible for the students, the researcher prepared printed pages including intensifiers along with related listening parts.

\section{Data Collection Procedure}

Forty-three male sophomore students participated in the study. They belonged to two intact groups: They formed one experimental group (audio input enhancement) and one control group. An English - Beginner Test was administered at the commencement of the study to assure the homogeneity of all the participants. After determining the level of proficiency of the students, a pre-test consisting of 20 multiple-choice items on English intensifiers was administered to both groups to ascertain that the students' knowledge of the target forms was more or less at the same level. Subsequently, English intensifiers were taught to both groups in sessions during 2 months. To be more precise, the teacher taught two English intensifiers during each session. In the audio input enhancement group, the learners were exposed to the target forms through audio materials before 
observing them in the printed form. The teacher increased the volume of the intended listening files in order to provide the participants with the enhanced target forms. The teacher sometimes provided short explanations for the intensifiers at the request of the participants. The control group, however, received only the printed file but no audio input. In other words, the intensifiers were taught through conventional methods. At the end of the last session, the immediate post-test was given to the participants in both groups to examine the short-term effect of the treatment on the participants' knowledge of intensifiers. Three weeks later, in order to evaluate the long-term effect of the treatment, the delayed post-test was administered to the participants in the experimental group. Finally, the data were gathered and analysed.

\section{FINDINGS}

Firstly, in order to indicate whether there is any significant difference in the performance of the two groups at the beginning, an independent samples t- test was applied. Table 1 reveals the descriptive statistics regarding the participants' pre-test scores in both groups, i.e. Experimental Group $(\mathrm{M}=5.17, \mathrm{SD}=1.82)$ and Control Group $(\mathrm{M}=5.90$, $\mathrm{SD}=2.26$ )

Table 1

Descriptive statistics

\begin{tabular}{lrccc}
\hline Groups & $\mathrm{N}$ & $\mathrm{M}$ & $\mathrm{SD}$ & Std.Error Mean \\
\hline Experimental & 23 & 5.17 & 1.825 & .381 \\
\hline Control & 20 & 5.90 & 2.269 & .507 \\
\hline
\end{tabular}

The results of the independent samples t-test are provided in Table 2.

Table 2

Independent samples t- test for pre - test scores

\begin{tabular}{|c|c|c|c|c|c|c|c|c|c|}
\hline & \multicolumn{6}{|c|}{ Leven's test for equality of variance } & \multicolumn{3}{|c|}{ T-test for equality of means } \\
\hline & \multirow[t]{2}{*}{$\mathrm{F}$} & \multirow[t]{2}{*}{ Sig } & \multirow[t]{2}{*}{$\mathrm{T}$} & \multirow[t]{2}{*}{ Df } & \multirow[t]{2}{*}{ Sig } & \multirow[t]{2}{*}{$\begin{array}{l}\text { Mean } \\
\text { difference }\end{array}$} & \multirow[t]{2}{*}{$\begin{array}{l}\text { Standard } \\
\text { Error } \\
\text { difference }\end{array}$} & \multicolumn{2}{|c|}{$\begin{array}{l}95 \% \text { confidence } \\
\text { interval of the } \\
\text { difference }\end{array}$} \\
\hline & & & & & & & & $\begin{array}{l}\text { Lower } \\
\text { bound }\end{array}$ & $\begin{array}{l}\text { Upper } \\
\text { bound }\end{array}$ \\
\hline $\begin{array}{l}\text { Equal } \\
\text { variances } \\
\text { assumed } \\
\end{array}$ & 3.068 & .087 & 1.163 & 41 & .252 & -.726 & .625 & -1.987 & .535 \\
\hline $\begin{array}{l}\text { Equal } \\
\text { variances } \\
\text { not assumed }\end{array}$ & & & 1.145 & 36.439 & .260 & -.726 & .634 & -2.012 & .560 \\
\hline
\end{tabular}

As it is clear from Table 2, there is no significant difference $(t(41)=1.16, p>.05)$ in the performance of the two groups regarding their pre-test on English intensifiers. Therefore, it can be concluded that the participants' knowledge of the selected target forms is almost at the same level prior to the implementation of the treatment.

In order to test the first null hypothesis regarding the effect of audio input enhancement on EFL learners 'retention of intensifiers, an independent samples t-test was run, too. The descriptive statistics and the results of the independent samples t-test are presented in Tables 3 and 4. 
Table 3

Descriptive statistics

\begin{tabular}{lcccc}
\hline Groups & N & M & SD & Std.Error Mean \\
\hline Experimental & 23 & 9.57 & 2.590 & 0.540 \\
\hline Control & 20 & 7.85 & 2.183 & 0.488 \\
\hline
\end{tabular}

Table 4

Independent samples t- test for post - test scores

\begin{tabular}{|c|c|c|c|c|c|c|c|}
\hline & \multicolumn{2}{|c|}{$\begin{array}{c}\text { Levene's Test for } \\
\text { Equality of Variances }\end{array}$} & \multicolumn{4}{|c|}{ t-test for Equality of Means } & \multirow{2}{*}{$\begin{array}{l}\text { Effect } \\
\text { Size }\end{array}$} \\
\hline & $\mathrm{F}$ & Sig. & $\mathrm{t}$ & df & Sig & $\begin{array}{l}\text { Mean } \\
\text { Difference }\end{array}$ & \\
\hline $\begin{array}{l}\text { Equal variances } \\
\text { assumed }\end{array}$ & 1.007 & 0.322 & 2.327 & 41 & 0.025 & 1.715 & \multirow{2}{*}{0.341} \\
\hline $\begin{array}{l}\text { Equal variances } \\
\text { not assumed }\end{array}$ & & & 2.356 & 40.968 & 0.023 & 1.715 & \\
\hline
\end{tabular}

Based on the given information in Tables 3 and 4, there is a significant difference in the performance of the experimental group $(\mathrm{M}=9.57, \mathrm{SD}=2.59)$ and the control group $(\mathrm{M}=7.85, \mathrm{SD}=2.18)$ regarding their post - test on English intensifiers, $\mathrm{t}(41)=2.32, \mathrm{p}<$ .05. Its effect size was also calculated. According to Cohen (1988), it represented a medium effect size $($ Eta squared $=.20$, small; Eta squared $=.50$, medium; Eta squared $=$ .80 , large). As is apparent from the results, audio input enhancement had a significant effect on EFL learners' retention of intensifiers. Therefore, the first null hypothesis was rejected.

In order to test the second null hypothesis concerning the long-term effect of audio input enhancement on EFL learners' retention of English intensifiers, a paired samples t-test was applied. Tables 5 and 6 indicate the results.

Table 5

Descriptive statistics

\begin{tabular}{lcccc}
\hline & $\mathrm{N}$ & $\mathrm{M}$ & $\mathrm{SD}$ & Std.Error Mean \\
\hline Post-test & 23 & 9.57 & 2.590 & 0.540 \\
\hline Delayed-test & 23 & 9.39 & 2.25 & 0.469 \\
\hline
\end{tabular}

Table 6

Paired samples t- test for delayed- test scores

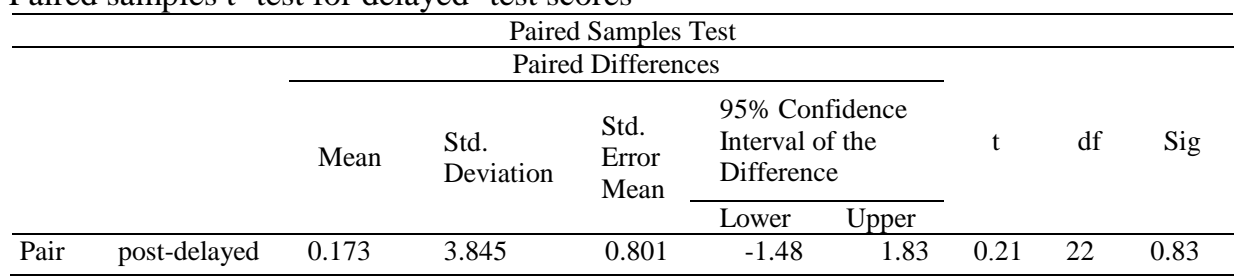


Table 6 presents the results of the dependent samples t-test used to compare the performance of the participants in the experimental group on the post-test and delayed post-test. As indicated in Tables 5 and 6, the difference between the participants' performance on the post-test $(\mathrm{M}=9.57, \mathrm{SD}=2.59)$ and the delayed post-test $(\mathrm{M}=9.39$, $\mathrm{SD}, 2.25$ ) was not statistically significant, $\mathrm{t}(22)=.21, \mathrm{p}>.05$.In other words, audio input enhancement did not improve the participants' performance on the delayed -test. So, the second null hypothesis was confirmed.

\section{DISCUSSION}

The aim of this study was twofold. Firstly, it sought to investigate the short-term effect of audio input enhancement on the retention of English intensifiers. The results of the independent samples t-test indicated that the participants who were instructed through audio input enhancement significantly performed better than their control group counterparts regarding the immediate post-test on English intensifiers. In other words, the findings illustrated that manipulating audio materials to make the target forms more salient will increase learners' noticing effectively and prompt EFL learners' acquisition and retention of the target forms. The findings of the present study are in line with Sharwood Smith's $(1991,1993)$ claim that input enhancement is effective in developing grammar instruction in second/foreign language classrooms. The significant effect of the treatment might be attributed to the application of audio materials for teaching the target forms. Richards and Schmidt (2002) claimed that retention of taught materials (e.g. grammatical items and vocabulary) might be affected by "the quality of teaching, the interest of the learners, or the meaningfulness of the materials" (p. 457). Regarding this fact, the findings of the current study corroborate Seven and Engin's (2007) study which highlighted the efficacy of audio materials in making learning more permanent. They concluded that the application of the audio material for teaching enhances the learners' desire and motivation to learn lessons. Hence, students listen to lessons more carefully, have active participation in the class and learn whatever the teacher taught them more effectively. The findings of the study are also compatible with Seyedtajaddini's (2014) study, which investigated the effect of audio input enhancement on EFL learners' grammar learning from varying proficiency levels, which has been proved to be effective in language learning.

Although the effectiveness of audio input enchantment in the acquisition of the target forms has been acknowledged by some studies, the study conducted by Johnson (1992) and Murphy (1997) indicated that participants performed grammatical judgment tasks faster and more precisely in the written than in the aural mode. Similarly, Cho and Reinders (2013) conducted a study that attempted to investigate the effect of aural input on the acquisition of the passive structure. The findings revealed no significant effect for the manipulated input on the acquisition of the target forms.

The second hypothesis attempted to explore the long-term effect of the treatment on EFL students' intensifier knowledge development. The results of the dependent samples t-test indicated that the effect on the retention of the English intensifiers derived from 
the immediate post-test was not stable. One possible explanation may be that raising students' attention as well as noticing through audio input enhancement might have triggered short-term memory, which caused the improvement of the participants' performance on the immediate post-test, but did not lead to a successful performance in long run. In line with this argument, Reinder (2005) claimed using such methods, which involve learners in more cognitive demanding activities, lead to a greater and longer retention of the learned items. Therefore, in order to develop the participants' long-term retention of English intensifiers, more additional processing on input is required.

The findings of the study are in line with Jabbarpoor and Tajeddin' (2013) study, indicating that although the participants in the enhanced group outperformed those in other groups regarding the post-test, they indicated no significant enhancement on the delayed-test.

As can be noticed in all above-mentioned investigations, the results obtained from enhancement studies differ widely. Some of these studies failed to reveal that input enhancement could be effective in triggering learning of the grammatical forms. Observed differences in the results may be attributed to different methodologies, procedures and measuring instruments used by researchers in these studies. It is worth nothing that it is not yet obvious which grammatical forms are more susceptible to input enhancement. This fact can be another reason for observed differences in the findings of these studies. Although, the wide array of differences in the results make these studies incomparable, the basic premise of all these studies is that, when learners fail to notice target forms in input, instructional treatment comes into play to draw their attention to them.

\section{CONCLUSION AND IMPLICATIONS}

The findings of the study confirmed short -term effect of audio input enhancement. In other words, it was founded that the experimental group greatly benefited from audio input enhancement treatment in the learning of English intensifiers. The findings also revealed that enhancing the specific target forms could trigger the noticing of that feature and its subsequent intake. In fact, careful attention to what has been taught justifies the rationale behind the findings. According to Han, Park and Combs (2008) input enhancement is based on the assumption that comprehensible input is required for second language acquisition, and the only input which is noticed by learners can affect the language acquisition. Consequently, noticing is essential and efficient in language learning (Schmidt, 2001). Several researchers such as Skehan (1998) and Schmidt (2010) also came up with similar findings.

The findings of the present study also support Leow's (2001) claim that designing language instructions and classroom activities in such a way that they efficiently raise learners' noticing of the new target forms while having interaction with L2 input is greatly profitable.

Moreover, the findings presented no significant effect for the manipulated input on the long-term retention of the target forms. It is worth noting that using input enhancement 
results in shallow processing of input, which cannot be effective in triggering the longterm memory.

To sum up, the application of audio input enhancement as a teaching method can help EFL learners, who have limited exposure to L2 input, pay more attention to the target forms and, consequently, learn instructed forms more effectively. However, they should attend to the acquired forms more consciously in order to retain them for a long period.

Limitations of the current study suggest several areas for future research. The current study indicated a significant effect of audio input enhancement on learning and retention of the targeted forms for male learners, but not female ones. Hence, further studies should address how gender mediates learning and retention of target structures through audio input enhancement. Moreover, focus of this study was on English intensifiers, More researchers are advised to conduct the same study with other grammatical structures to generalize the findings better.

This study has some pedagogical implications for language teachers and material designers. The findings of this study can be helpful for teachers in teaching grammatical structures to EFL learners. Audio input enhancement can be applied as a technique to draw learners' attention to special grammatical structures of input and, consequently, facilitates their acquisition of the targeted forms. Developing new materials to raise audio input in conventional classes provided with more written input should be taken into account by material designers. It should also be mentioned that this study has improved the focus on form literature by focusing on EFL students to whom the targeted structure under investigation, namely English intensifiers, had not been taught before.

\section{ACKNOWLEDGEMENT}

We are immensely grateful to Ghodrat Hassani, PhD Student in Translation Studies, for his comments on an earlier version of the manuscript, although any errors are our own and should not tarnish the reputations of these esteemed persons. 


\section{REFERENCES}

Allerton, D. J. (1987). English intensifiers and their idiosyncrasies. In S. Ross \& T. Terry (Eds.), Language Topics: Essays in Honour of Michael Halliday (Vol. 2). Amsterdam: John Benjamins Publishing Company.

Ary, D., Cheser Jacobs, L., Sorensen Irvine, C., \& Walker, D. A. (2014). Introduction to Research in Education. Wadsworth: Cengage Learning.

Ayiewbey, S. (2013). An investigation to the effects of textual enhancement on the learning of english past tensein the context of iranian learners. Technical Journal of Engineering and Applied Sciences, 1217-1222

Barnfield, K., \& Buchstaller, I. (2010). Intensifiers on tyneside: longitudinal developments and new trends. English World-Wide, 31(3), 252-287.

Benati, A. (2001). A comparative study of the effects of processing instruction and output-based instruction on the acquisition of the Italian future tense. Language Teaching Research, 5(2), 95-127.

Bertrand, W. (n.d.). English Test- Beginner. Retrieved from http://www.williambertrand.fr/pdf/Exercises_Tests_Beginner_Keys.pdf

Cho, M., \& Reinders, R. (2013). The effects of aural input enhancement on L2 acquisition. In J. M. Bergsleithner, S. N. Frota, \& J. K. Yoshioka, (Eds.), Noticing and second language acquisition: Studies in honor of Richard Schmidt.(pp. 133-148).

Cohen, J. W. (1988). Statistical power analysis for the behavioural sciences (3nd ed). Hillsdale, NJ: Lawrance Erlbaum Associates

Combs, C. H. (2009). What cognitive processes are triggered by input enhancement? Working papers in TESOL \& Applied Linguistics [Special issue], 4.

Doughty, C. (2001). Cognitive underpinning of focus on form. In. P. Robinson (Eds.). Cognition and Second Language Acquisition, (pp. 206-257). Cambridge: CU.

Ellis, N. C. (1993). Rules and instances in foreign language learning: Interactions of implicit and explicit knowledge. European Journal of Cognitive Psychology, 5(3), 289319.

Ellis, N. C. (1995). Consciousness in second language acquisition: A review of field studies and laboratory experiments. Language Awareness, 4(3), 123-146.

Ellis, R. (1997). SLA research and language teaching. Oxford: Oxford University Press.

Eslami-Rasekh, A. S., \& Mardani, M. (2010). Investigating the effects of teaching apology speech act, with a focus on intensifying strategies, on pragmatic development of EFL learners: The Iranian context. The International Journal of Language, Society and Culture, 30, 96-103. 
Gass, S. M. (1997). Input, interaction, and the second language learner. Mahwah, NJ: Lawrence Erlbaum.

Han, Z., Park, E. S., \& Combs, C. (2008). Textual enhancement of input: Issues and possibilities. Applied Linguistics, 29, 597-618.

Jabbarpoor, Sh., \& Tajeddin, Z. (2013). The effect of input enhancement, individual output, and collaborative output on foreign language learning. RESLA, 26, 267-288.

Jabbarpoor, Sh., \& Abdollahzadeh, E. (2013). Textual enhancement across linguistic structures: EFL learners' acquisition of English forms. Journal of Language and Translation, 2/5, 69-78.

Johnson, J. (1992). Critical period effects in second language acquisition: The effect of written versus auditory materials on the assessment of grammatical competence. Language Learning, 42, 217-48.

Kim, Y. (2006). Effects of input elaboration on vocabulary acquisition through reading by Korean learners of English as a foreign language. TESOL Quarterly, 40(2), 341-373.

Krashen, S. (1981). Second language acquisition and second language learning. Oxford: Pergamon Press.

Larsen-Freeman, D., \& Long, M. (1991). An introduction to second language acquisition research. London: Longman.

Leedy, P. D. \& Ormrod, J. E. (2010). Practical research: Planning and design (9th ed.). Upper Saddle River, NJ: Prentice Ha.

Leow, R. P. (2000). A study of the role of awareness in foreign language behavior: Aware vs. unaware learners. Studies in Second Language Acquisition, 22(4), 557-584.

Leow, R. P. (2001). Do learners notice enhanced forms while interacting with the L2? An online and offline study of the role of written input enhancement in L2 reading. Hispania, 84(3), 496-50.

Long, M. (1991). Focus on form: A design feature in language teaching methodology. In K.DeBot, R. Ginsberg, \& C. Kramsch (Eds.), Foreign language research in crosscultural perspective (pp. 39-52). Amsterdam: Benjamins.

Méndez-Naya, B. (2008). Special issue on English intensifiers. English Language and Linguistics, 12(2), 213-219.

Murphy, V. (1997). The effect of modality on a grammaticality judgment task. Second Language Research, 13, 34-65.

Nassaji, H. (2009). Interactional feedback and L2 learners' development. International Conference, University of Yazd, Yazd, Iran.

Overstreet, M. (1998). Text enhancement and content familiarity: The focus of learner attention. Spanish Applied Linguistics, 2, 229-258. 
Overstreet, M. (2002). The effects of textual enhancement on second language learner reading comprehension and form recognition (Doctoral Dissertation). Available from Pro Quest Dissertations and Theses databases. (UMI No. 3070405).

Quirk, R., Greenbaum. S., Leech, G., \& Svartvik, J. (1985). A comprehensive grammar of the English language. New York: longman.

Rahimpour, M., Salimi, A., \& Farrokhi, F. (2012). The impact of extensive and intensive focus on form strategies on EFL learner' oral accuracy. International Journal of Applied Linguistics \& English Literature, 1(6), 37-43.

Reinders, H. (2005). The effects of different task types on second language learners' intake and acquisition of two grammatical structures (Unpublished doctoral dissertation). University of Auckland, Auckland.

Richards, J. C., \& Schmidt, R. (2002). Longman dictionary of language teaching and applied linguistics (3rdEd.). London: Pearson Education.

Richards, J. C., \& Trew, G. (1943). Tactics for Listening (3rd ed.). Oxford. Oxford University Press.

Saslow, J., \& Asher, A. (1958).Top Notch, English for Today's World, 3-B. Pearson Longman.

Schmidt, R. (1990). The role of consciousness in second language learning. Applied Linguistics, 11(2), 129-158.

Schmidt, R. (1994). Deconstructing consciousness in search for useful definitions for applied linguistics. AILA Review, 11, 11-26.

Schmidt, R. (2001). Attention. In P. Robinson (Ed.), Cognition and Second Language Instruction (pp. 3-32). Cambridge: Cambridge University Press.

Schmidt, R. (2010). Attention, Awareness, and individual differences in language learning. In W. M. Chan (Eds.), Proceedings of CLaSIC (pp. 721-737). Singapore: National University of Singapore, Centre for Language Studies.

Skehan, P. (1998). A cognitive approach to language learning. Oxford: Oxford University Press

Seven, M. A., \& Engin, A.O. (2007). The importance and effect of using aid materials in foreign language teaching. August 2007. Retrieved 19 September, 2016 from http://files.eric.ed.gov/fulltext/ED497456.pdf

Seyedtajaddini, K. (2014). The impact of audio input enhancement on EFL Learners' Grammar Learning from varying proficiency levels. Procedia - Social and Behavioral Sciences, 86, 342-551. 
Sharwood Smith, M. (1991). Speaking to many minds: On the relevance of different types of language information for the L2 learner. Second Language Research 7, 118132.

Sharwood Smith, M. (1993). Input enhancement in Instructed SLA: Theoretical bases. Studies in Second Language Acquisition, 15, 165-17.

Sharwood Smith, M. A. (1981). Consciousness-raising and the second language learner. Applied Linguistics, 2(2), 159-168.

Spada, N. (1997). Form-focused instruction and second language acquisition: A review of classroom and laboratory research. Language Teaching, 30(2), 73-87.

VanPatten, B. (1996). Input processing and grammar instruction: Theory and research. Norwood, NJ: Ablex.

Wong, W. (2003). Textual enhancement and simplified input: Effects on L2 comprehension and acquisition of non-meaningful grammatical form. Applied Language Learning, 13(2), 109-132. 